\title{
NA KRAWĘDZI MIĘDZY DWIEMA SWOIMI OJCZYZNAMI... HISZPAŃSKIE ROZRACHUNKI POETY MARCJALISA
}

\author{
Zbigniew Danek ${ }^{1}$ \\ https://doi.org/10.18778/8220-421-6.07
}

\begin{abstract}
This chapter deals with the issue of the motivations that made Martialis, a Spanish native of Bilbilis, decide to leave the capital of the Empire after many years of fruitful residence in Rome and return to his native land. Analysing the references to the Spanish land that can be found in the epigrams of Martialis, it can be assumed that the strongest motivation for this was his memory of his home town, that is of Bilbilis, which certainly dominates over the sentiment to the Spanish land as an ethnic and geographical whole. It should be emphasized, however, that Martialis, who treated both Rome and his home town with a sufficient degree of criticism, in returning to his homeland, was guided not so much by sentiment and emotion, as by the need for inner peace, so desirable for a man who is closing his life balance.
\end{abstract}

Keywords: Martialis, Spain, return, motivation.

Słowa kluczowe: Marcjalis, Hiszpania, powrót, motywacje.

W roku 98, pierwszym roku pryncypatu Trajana, po wielu latach owocnego pod niejednym względem pobytu w Rzymie, poeta Marcjalis decyduje się na opuszczenie Wiecznego Miasta

1 Uniwersytet Łódzki, Wydział Filologiczny, Katedra Filologii Klasycznej, zbigniew.danek@uni.lodz.pl. 
- opuszczenie, co pokażą następne lata, definitywne. Wraca do ojczystej ziemi hiszpańskiej, a dokładniej do swojej małej ojczyzny, jak można nazwać noszącą dumną nazwę Augusta Bilbilis miejscowość, w której przyszedł na świat i spędził pierwsze lata życia. U podstaw jego decyzji leżą z całą pewnością motywacje jednego i drugiego rodzaju, a więc tak pozytywne - czyli siła atrakcyjna, z jaką wciąż, czy też na nowo, oddziałuje na niego zapamiętany obraz rodzinnej Hiszpanii - jak też czynnik przeciwny, przesyt oraz zmęczenie życiem wielkiego miasta. Ta właśnie wewnętrzna „dwubiegunowość" znajduje wyraz w szeregu utworów dziesiątej księgi epigramów Marcjalisa² ${ }^{2}$, którą - za jednym z komentatorów - można określić jako Buch des Übergangs, czyli „księgę, gdzie dokonuje się przejście” poety od stanu względnego zadowolenia, wywołanego atrakcyjnością życia wielkomiejskiego, do podjętej z całą determinacją decyzji o wyjeździe ze stolicy rzymskiego imperium ${ }^{3}$. Dla konstruktywnie myślącego badacza istotniejsze będą z pewnością te czynniki, które pozytywnie motywowały Marcjalisa do podjęcia niemałego wysiłku, jakim była uciążliwa podróż przez niemal połowę Europy i ponowna adaptacja w dawno opuszczonej ojczyźnie - i na tych głównie czynnikach skupi się uwaga piszącego niniejsze słowa.

O tym, że zamiar opuszczenia Rzymu powoli dojrzewał w świadomości Marcjalisa, świadczy treść epigramu trzynastego księgi dziesiątej, w którym poeta zwraca się do nieznanego skądinąd dawnego przyjaciela Maniusza jako osoby na tyle bliskiej, że decyduje się Marcjalis na podróż do Hiszpanii, by móc zobaczyć owego towarzysza dawnych lat. W tym utworze, traktującym wspomnianą podróż jako niemal „wyjazd urlopowy”

2 Cytowane fragmenty utworów Marcjalisa pochodzą z wydania teubnerowskiego: M. Valerii Martialis Epigrammaton libri XIV, ed. W. Heraeus. (1925) Lipsk: Bibliotheca scriprorum et Greacorum Teubneriana; tłumaczenia własne autora (Z. Danek).

3 Por. Marcus Valerius Martialis, 2004: 8 „Das zehnte Buch ist ein Buch des Übergangs. [...] eine innere Wandlung Martials: Der in Rom alt gewordene Dichter fasst den Entschluss, in seine Heimat Spanien zurückzukehren“. 
(Urlaubsreise) ${ }^{4}$, Rzym wciąż jeszcze pozostaje miejscem, w którym realizują się marzenia poety, wciąż jeszcze dalekiego od tak radykalnej późniejszej decyzji ${ }^{5}$. Powzięty przez niego zamiar definitywnego opuszczenia Rzymu z całą wyrazistością odzywa się dopiero w dalszej części zbioru. Dodajmy w tym miejscu, że poza wspomnianymi powyżej czynnikami odstręczającymi było też wiele miłych aspektów rzymskiej egzystencji poety, do jakich zaliczymy możliwość spędzania czasu we własnej wiejskiej posiadłości, z którą też żegna się Marcjalis w epigramie 92, przekazując zabudowania, ołtarz "gromowładnego" i cały pięknie opisywany drzewostan „w wierne ręce" dobrze znanego sobie Mariusza. Ów miły obrazek świadczy zresztą o tym, że wbrew narzekaniu poety na trudności utrzymania się przy życiu w Rzymie nie znajdujemy go w przeddzień wyjazdu w kryzysowej sytuacji dojmującego niedostatku, a trudno też mówić o jakimś zniechęceniu Marcjalisa - co sugerują niektóre komentarze ${ }^{6}$ - do życia w stolicy imperium spowodowanym niełaską dworu cesarskiego po tym, jak dokonała się radykalna zmiana na szczycie władzy. Zarówno bowiem Domicjan, kończący swe panowanie wraz z zamachem, którego stał się ofiarą, nie okazywał schlebiającemu mu Marcjalisowi jakichś względów nadzwyczajnych ${ }^{7}$, jak i panujący

4 J.w. (Heil, 2004: 15) „Man hat eher den Eindruck, dass es sich um eine Urlaubsreise als um einen endgültigen Abschied handelt”.

$5 \mathrm{Na}$ to, że Marcjalisa do podjęcia planowanej podróży do Hiszpanii motywuje wtedy jeszcze osoba przyjaciela, nie zaś potrzeba ujrzenia tej ziemi, a Rzym jako centrum kulturowe wciąż jeszcze urasta do rangi ideału, słusznie zwraca uwagę A. Heil (Heil, 2004: 81-82 „Martial weder auf die Vorzüge seiner Heimat noch auf die Probleme des römischen Alltags hinweist, um seine Entscheidung zu motivieren. Vielmehr wird überraschenderweise ein Freund [...] als der einzige Grund für die Heimreise angegeben [...] Dieser Begriff von Rom ist, abgelöst von der geographischen Entität, zur Idee geworden)“.

6 Por. Martial, 2003: 4 „M.'s real reason for returning to Spain could have been that he was so closely associated with Domitian's regime that he could not expect patronage from Nerva and Trajan".

7 Por. Cytowska, Szelest, 1992: 323: Natomiast stosunek Domicjana do Marcjalisa był bardzo chłodny i oficjalny. Wprawdzie 
po nim Nerwa, a następnie Trajan, nie darzyli poety jakąś widoczną niechęcią, a trudno też utrzymywać, że pozycja znanego twórcy epigramów, tak popularnego w szerokich kręgach eleganckiego świata Rzymu, uzależniona była wyłącznie od faworu, jaki zyskiwał na dworze princepsa. Podsumowując powyższe spostrzeżenia można zatem przyjąć, że bilans wieloletniego pobytu Marcjalisa w stolicy imperium wcale nie przedstawiał się niekorzystnie i bardziej niż negatywne aspekty tamtejszej egzystencji wpłynęły na jego decyzję hiszpańskie reminiscencje, wciąż żywe w jego świadomości, oraz oczekiwania, jakie z Hiszpanią wiązał.

Mówiąc o obrazie ziemi hiszpańskiej, jaki wyłania się z utworów Marcjalisa, należy przede wszystkim zastrzec, że nie jest on - jak to się nieraz czyta - „pełen liryzmu”, a z całą pewnością nie jest obrazem bezkrytycznym. Można mówić o wyrazistej, wręcz „ostrej” pamięci (sharp memory), z jaką utrwaliły się w świadomości poety te i inne hiszpańskie realia ${ }^{9}$, przedstawiane przez niego w sposób bardzo konkretny i znamionujący pewien zmysł gospodarski. Kiedy na przykład przeciwstawia niedogodnościom rzymskiej egzystencji wolne od takich kłopotów życie w Hiszpanii, pojawiają się w jego opisie obfitość opału, suto zastawiony stół, czy toga, dobrze zachowana, kiedy nie trzeba jej na co dzień używać, składające się na określone „materialne zalety" (materielle Vorteile) ${ }^{10}$ owego błogosławionego życia. Wy-

kilkakrotnie mówi epigramatyk, że cesarz chętnie czyta jego utwory i chwali, ale nigdy nie zaprosił poety do siebie, chociaż na dworze cesarskim bywał na przykład aktor mimiczny Latinus. Nie brał też Marcjalis udziału w żadnym agonie poetyckim i nigdy nie otrzymał od cesarza pomocy materialnej.

8 Por. Szelest, 1963: 237: „ładnie i pełne liryzmu opisy Hiszpanii”.

9 Por. Dalby, 2000: 104: „There was bad wine of Spain too, faex Laietana, "Laietan dregs", from the neighbourhood of modern Barcelona, no doubt a sharp memory of Martial's homeland".

10 Por. Baumbach, 2004: 341: „er zeichnet ein realistisches Bild vom Leben in der Heimat, das sich auf materielle Vorteile im Vergleich zu Rom Beschränkt: Spanien bietet eine mit dem Lebensnotwendigen ausgestattete Hütte, genug $\mathrm{Holz}$, reichlich Ernteerträge sowie erschwingliche Marktpreise". 
chwalając z kolei, cenione zresztą także przez Pliniusza, wina hiszpańskie, nie waha się wspomnieć również o nędznej jakości winie z północno-wschodniej Hiszpanii ${ }^{11}$, a pisząc o nabytkach, jakie stały się udziałem niejakiego Sabellusa, wylicza wśród nich zestaw naczyń, będący przykładem niezdarnej roboty jakiegoś hiszpańskiego garncarza (IV,46,14-16). Nie jest zresztą zbyt wnikliwy i oryginalny, kiedy wydobywa różne detale składające się na obraz ojczystego kraju. Pisząc na przykład o znanej z różnego rodzaju doskonałych produktów Betyce, ogranicza się do stereotypu, jakim w jego ujęciu staje się znakomitej jakości tamtejsza wełna ${ }^{12}$, a $z$ drugiej strony wypowiadając się na temat świetnej skądinąd hiszpańskiej przędzy wełnianej, za przykład podaje wyłącznie wełnę z Betyki ${ }^{13}$, nie wspominając zupełnie innych regionów hodowlanych.

Obserwując występowanie na przestrzeni całego zbioru epigramów Marcjalisa sielankowych motywów pogodnego życia na hiszpańskiej prowincji oraz obrazów pełnego atrakcji życia wielkomiejskiego dostrzegamy zresztą, że ocena, jaką zyskują u poety te dwa odmienne sposoby życia nie utrzymuje się na tym samym poziomie, ani nawet nie wykazuje jednoznacznej tendencji, kierującej kryteria wyboru ku jednej z dwóch alternatywnych możliwości. Można bowiem mówić, że - co podkreśla Elena Merli - w księgach „środkowych” całego zbioru epigramów, to znaczy w księgach 4-9, poeta wyraźnie łagodzi opozycję między jednym a drugim sposobem życia, odnajdując doskonałe otium niejako „w kontekście” bytowania w warunkach miejskich ${ }^{14}$, natomiast

11 Dokładnie o wzmiankowanym powyżej (przyp. 9) winie w regionu Laietanii - I,26,9-10: „A copone tibi faex Laletana petatur, si plus quam decies, Sextiliane, bibis".

12 Epigr. V,37,7; VIII,28,5-6; IX,61,1-3; XII,65,5; XII,98,1-2; XIV [Apophoreta], 133.

13 Por. Antczak, 2016: 349: „Należy podkreślić, że za każdym razem, artykułując piękno runa hiszpańskiego, Marcjalis mówi o runie z owiec betyckich".

14 Merli, 2006: 328. „Books 4-9 where otium is sometimers situated in an urban context, while the opposition to life in the countryside recedes into the background". 
tendencja do ucieczki w opisywane realia rodzinnej Bilbilis daje znać o sobie w księgach początkowych, a także w księdze dziesiątej oraz - częściowo - dwunastej. Ów nawrót akcentów przeciwstawiających miejskiej egzystencji życie na wsi szczególnie zaznacza się - zdaniem wspomnianej badaczki - w dziesiątej księdze epigramów, która w sposób pełniejszy i zarazem niejednoznaczny, lecz dostatecznie wyraźnie, nawiązuje do motywów znanych z ksiąg pierwszej i drugiej15. Wskazana prawidłowość świadczy - jak sądzę - nie tyle o chwiejności nastrojów poety, lecz o tym, iż po latach, w których wciąż trudno było mu w pełni adaptować się do warunków, jakie oferowała rzymska metropolia, ta adaptacja jednak nastąpiła, po czym jednak z wiekiem i postępującym wyczerpaniem życiowym odrodziła się w nim idea spokojnego życia w bliskich mu realiach ziemi rodzinnej. Można też utrzymywać, że odezwały się w nim, nieco uśpione ponętami życia wielkomiejskiego, uczucia patriotyczne.

Mówiąc o patriotyzmie Marcjalisa, czyli o jego przywiązaniu do ziemi ojczystej, stajemy przed problemem, na który wskazuje Sullivan, wyróżniający kilka aspektów, czy raczej kilka stopni, tego patriotyzmu, problemem, który w jakiejś mierze dotyka wszystkich członków ludzkich zbiorowości, koncentrycznie zawierających się jedna w drugiej. Mówimy o kimś: rodak z Bałut, łodzianin, Polak, Europejczyk, i kolejne te określenia odpowiadają kolejnym stopniom patriotycznej tożsamości owego człowieka, co jednak nie znaczy, że w równym stopniu utożsamia się on z każdą ze zbiorowości nazywanych powyższymi określeniami. W takiej sytuacji znajduje się również nasz autor epigramów, który zdaniem wspomnianego badacza w jakimś stopniu darzy patriotycznym „sentymentem” Hiszpanię jako taką, mimo że uczucia, jakie żywi w stosunku do „Celtyberii” i rodzinnej Bilbilis, przewyższać mają jego ogólnie pojętą „hiszpańskość”16, czyli

15 Ibidem. „By contrast, Book 10 returns to the motifs encountered in Books 1-2, but here they become more complex and problematic". 16 Sullivan, 2004: 175. „It must not be assumed that Martial expresses no general patriotic sentiments about Hispania as a whole. It is in his poems that the idea of Spain as a national entity is first 
świadomość, że jest synem ziemi hiszpańskiej jako pewnej zintegrowanej całości. Wątpliwości dotyczące wzajemnych relacji, w jakich pozostają kolejne te postaci, czy też stopnie jego hiszpańskiego patriotyzmu, niewątpliwie znajdujące wyraz w zbiorze epigramów Marcjalisa, można wyjaśniać obserwując odniesienia do określonych punktów i przestrzeni hiszpańskiego krajobrazu, które w określonym następstwie czasowym pojawiają się w jego utworach.

Pojęciem generalnie nadrzędnym będzie tu treść zawarta w samej nazwie Hiszpanii, która w zbiorze epigramów Marcjalisa występuje aż, czy tylko, dwunastokrotnie w sytuacjach, jakie bynajmniej nie znamionują jakiejś szczególnej więzi emocjonalnej łączącej poetę z tą ziemią w całej jej geograficznej rozciągłości. Deklaratywne początkowe „nasza Hiszpania” (Nostraeque laus Hispaniae ${ }^{17}$ zastępuje bowiem później częste sytuacje, w których poeta wzmiankuje różne obiegowo wiązane z tą krainą produkty, jak wspomniane już wyroby garncarskie, wypełnione winem szklane pojemniki $(\mathrm{V}, 16,7)$, czy uznanej marki hiszpańskie srebro (VII,86,7), czyniąc to z całkowitą obojętnością człowieka wiążącego z ową marką hiszpańską wyłącznie określoną wartość handlowo-użytkową wymienianych produktów. Dodajmy, że sytuacje z ostatniej księgi epigramów Marcjalisa - w których broni się on przed tym, by jego nowe utwory odczytywano jako „hiszpańskie”18 oraz uskarża się na odgłosy, jakie wywołuje hałaśliwa obróbka słynnego hiszpańskiego złota (57,9-10) - wybrzmiewają wręcz akcentami niechęci do kraju, w którym przyszło mu spędzić ostatnie lata życia.

propounded (cf. nostraeque laus Hispaniae, I,49,2) even if his feelings for Celtiberia and Bilbilis outweigh his broader Hispanismo".

17 Za podobną deklarację można uznać późniejsze Hispanis ego contumax capillis $(\mathrm{X}, 65,7)$, niemniej mało chwalebny atrybut, na który w przytoczonych słowach powołuje się poeta, w żadnym stopniu nie znamionuje jego sentymentu do ziemi hiszpańskiej, czy też dumy z jego hiszpańskiego pochodzenia.

18 XII [wstęp], w. 27-8: „ne Romam, si ita decreveris, non Hispaniensem librum mittamus, sed Hispanum". 
Interesujące jest to, że Marcjalis w nikłym stopniu utożsamiając się z całą geograficzną Hiszpanią, wykazuje jednak niezwykły sentyment do głównej rzeki Półwyspu Iberyjskiego, jaką jest płynący przez ziemie dość odległe od jego miejsc rodzinnych Tag. Stwierdza, że poczytność jego epigramów daje mu większą satysfakcję niż stan, w którym owa, nazwana „moim Tagiem”, rzeka „napełniłaby go hiszpańskim złotem”19. Siebie samego przedstawia jako celtyberyjskiego pochodzenia „obywatela Tagu" (Tagique civis - X,65,4), którą to rzekę w innym jeszcze miejscu $(I V, 55,2)$ nazywa nie bez dumy „naszym Tagiem”. Może to świadczyć, że jakieś poczucie ogólnonarodowej, czy też ponadnarodowej, wspólnoty mieszkańców Półwyspu Iberyjskiego nie jest mu jednak obce, zwłaszcza że bardziej lokalna i bliższa mu geograficznie rzeka Hiber, czyli Ebro, jako taka w ogóle nie jest przez niego wzmiankowana. Dość często wspomina natomiast Marcjalis inne rzeki ziemi hiszpańskiej - głównie płynącą przez jego miejsca rodzinne Salonę oraz rzekę Baetis (dzisiejszy Gwadalkiwir), dającą nazwę wspominanej już Betyce i utożsamianą przez niego z tą właśnie krainą. Rzeki w ogóle zajmują tak znaczące miejsce w obrazie Hiszpanii, jaki oddaje on w swych epigramach, że można mówić o dość szczególnym, „rzecznym” patriotyzmie Marcjalisa.

Kolejny, zawężający perspektywę, szczebel owej tożsamości wyznaczają podziały administracyjne i etniczne, jakie dokonały się w obrębie całego iberyjskiego terytorium, wówczas - jak wiadomo - mającego w swym składzie trzy nierównej wielkości prowincje, spośród których najdalsza Lusitania, nie jest przez Marcjalisa w ogóle wzmiankowana, natomiast urodzajna śródziemnomorska Betyka - o czym mowa była powyżej - wzmiankowana jest w sposób stereotypowy. Tego wrażenia nie zacierają nawet epigram 61 z księgi IX, w którym poeta wielbi rosnący w stolicy owej prowincji platan, zasadzony swego czasu ręką Cezara, oraz epigram 98 z księgi XII, gdzie z równym uwielbieniem zwraca się on do rzeki dającej nazwę tej krainie, polecając jej

19 VII, 88, 7. „Quam meus Hispano si me Tagus impleat auro” (tłum. własne). 
zaprzyjaźnionego ze sobą Instancjusza, nowego namiestnika Betyki, gdyż brakuje w tych dość konwencjonalnych pochwałach akcentu jakiejkolwiek bliskości emocjonalnej piszącego i obiektów jego laudacji. Zdecydowanie natomiast deklaruje Marcjalis swój związek z trzecią i najbardziej rozległą z hiszpańskich prowincji, jaką była ówczesna Hispania Tarraconensis, opowiadając się jednak nie tyle Tarakończykiem, co poetą „zrodzonym z Celtów i Iberów" (IV,55,8).

Interesujące jest to, że autor epigramów, wyznając swoje celtyberyjskie pochodzenie, za każdym bodaj razem ujmuje rzecz „hendiadycznie”, artykułując niejako oddzielnie jeden i drugi element owego specyficznego określenia, oddającego dawno już zresztą zakończony proces asymilowania się w jedną grupę etniczną rdzennej ludności iberyjskiej pobrzeża późniejszej Tarakonii oraz napływowego elementu celtyckiego. Nazywa siebie „obywatelem Tagu, zrodzonym z Iberów i Celtów” (ex Hiberis et Celtis genitus Tagique civis - X,65,3-4), a swój wyjazd do Hiszpanii zapowiada jako powrót do kraju „Celtów i dzikich Iberów” (X,78,9), nie dając wszelako żadnego opisu ani charakterystyki owej uznanej za swoją etniczną ojczyznę Celtyberii. Ten brak bliższej perspektywy krainy bliskiej, wydawałoby się, naszemu poecie, jakieś wyjaśnienie znajduje w dedykacji epigramu 52 z księgi siódmej, gdzie wspominając byłego zarządcę Tarakonii Celera Marcjalis stwierdza, że ów Rzymianin swego czasu rządził „własnym narodem” poety oraz „celtyckimi iberyjczykami” (Ille meas gentes et Celtas rexit Hiberos - VII,52,3). Wyraźnie daje tutaj do zrozumienia, że lud, z którym łączy go więź ścisłej etnicznej przynależności, to społeczność skupiona wokół jego rodzinnej Augusta Bilbilis.

To właśnie miasto, cieszące się już wówczas municypalną samodzielnością oraz szeregiem udogodnień cywilizacyjnych ${ }^{20}$, a także jego okolice, opisuje Marcjalis ze szczególną wyrazistością.

20 Por. Damschen, 2004: 362: „Bilbilis Augusta war eine keltiberische Landschaft (municipium) mit römischem Bürgerrecht, eigener Verwaltung, einem Theater und Thermen in der Provinz Hispania Tarraconensis". 
W opisie pojawiają się okoliczne wzniesienia, góra Kaius ${ }^{21}$ i święty Wadaweron $(\mathrm{I}, 49,6)$, żyzna dolina o nazwie Watiweska $(\mathrm{IV}, 55,26)$, uroczy gaj Boterdum ${ }^{22}$, czy święty las dębowy Buradon (IV,55,23), jak również szereg mniejszych bliżej i dalej położonych miejscowości. Wyjątkowo eksponowane miejsce w tym obrazie jego ziemi rodzinnej zajmują różnego rodzaju zbiorniki i ciągi wodne, jeszcze jeden przykład wspomnianej już „akwarnej" percepcji świata naturalnego cechującej obraz Hiszpanii, jaki przynoszą utwory Marcjalisa. Poznajemy zatem jezioro Turgontus, źródła noszące nazwy Turasia i Tuetonissa ${ }^{23}$, a przede wszystkim płynące w owej krainie rzeki, jak Kongedus o ciepłych i wolno płynących wodach (I,49,9), czy lodowato zimna Nutha $(\mathrm{I}, 49,18)$, gasząca pragnienie Derceita $(\mathrm{I}, 49,17)$, czy Peteris o brzegach porośniętych krzewami różanymi ${ }^{24}$, nie wspominając już o pierwszoplanowej roli, jaka w tym lokalnym systemie rzecznym przypada wspomnianej powyżej Salonie ${ }^{25}$.

Z przedstawionych powyżej obserwacji wynika, że Marcjalis w nikłym jednak stopniu osadzał wyrażany niekiedy swój patriotyzm w realiach całej ziemi hiszpańskiej i nie był też w żadnym wypadku „szowinistycznym Tarrakończykiem”26, lecz za właściwą jego ojczyznę i ziemię, w jakiś sposób mu bliską, można uznać niewielką krainę, której ośrodek stanowiła jego rodzinna Bilbilis. Ten zdecydowanie lokalny patriotyzm, zanikający już w rzeczywistości epok późniejszych, ma swoje korzenie jeszcze w realiach rozbitej na bardzo autonomiczne poleis Grecji antycznej, a umocowanie swoje znajduje w federacyjnym

21 I,49,5: „Senemque Caium nivibus”; IV,55,2: “Caium veterem Tagumque nostrum".

22 I,49,7: „Et delicati dulce Boterdi nemus”; XII,18,11: “Boterdum Plateamque".

23 IV,55,21-22: „Turgontique lacus Turasiaeque, / Et parvae vada pura Tvetonissae".

24 IV,55,18: „Et textis Peterin rosis rubentem”.

25 I,49,12; IV,55,15: X,13,1; X,96,3; X,103,2; X,104,6; XII,2,3; XII,21,1; XIV,33,2.

26 Por. Martial, 2006: 394: „To this should be added the fact that Martial is not a chauvinistic Tarraconensis". 
charakterze republiki rzymskiej i późniejszej municypalnej strukturze rzymskiego imperium.

Powrót do miejsc, wydawałoby się, tak bliskich poecie nie przyniósł mu ostatecznie - jak wiadomo - ukojenia i satysfakcji emocjonalnej. Już na wstępie dwunastej księgi epigramów, powstałej po kilkuletniej niemocy twórczej w realiach rodzinnej Bilbilis, uskarża się on nie tylko na brak cywilizacyjnych udogodnień oraz grona dostatecznie wyrobionych odbiorców swojej poezji, ale również na dotykające go kąśliwe oszczerstwa ze strony tamtejszych obywateli (municipalium robigo dentium), i, w miejsce rzeczowej oceny jego twórczości, na zazdrość, czy wręcz złość, z jaką w kontaktach z nimi się styka (iudicii loco livor). Opracowania komentujące opisaną sytuację mocno akcentują emocjonalny, wręcz idealistyczny, aspekt owego braku satysfakcji poety z jego decyzji o powrocie do ojczyzny, kiedy to wcześniejsze „marzenie na jawie o ziemi hiszpańskiej" (Martialis Tagträumerei von Spanien - Baumbach, 2004: 341) przeradza się w nim w bolesne rozczarowanie życiem prowincjonalnym ${ }^{27}$ i dojmującą tęsknotę za utraconym Rzymem ${ }^{28}$. Ponieważ taki opis stanu wewnętrznego poety przeczy dostrzeżonemu powyżej brakowi egzaltacji w sposobie przedstawienia przez niego życia w Hiszpanii, konieczne wydaje się zwrócenie uwagi na to, że Marcjalis nie decydował się na powrót do miejsc rodzinnych z jakąśs świetlaną wizją niezwykłej glorii, w której miałby żyć wśród swoich rodaków. Na tyle był realistą i na tyle znał owych ludzi, że już przed wyjazdem z Rzymu liczył się z tym, że okażą mu oni aspera corda, to znaczy szorstkie i nieprzyjazne serca i nawet ostrzegał owych

27 Por. Szelest, 1963: 17: „Dlatego powrót do Hiszpanii i życie w małym prowincjonalnym mieście było dla niego jaskrawym kontrastem, tym boleśniejszym, że ojczyzna, która stawała niejednokrotnie przed oczyma autora ze swym pięknym krajobrazem i miała mu zapewnić dobrobyt i szczęście, nie spełniła nadziei”.

28 Por. Cytowska, Szelest, 1992: 316: „Poetę dręczy przede wszystkim tęsknota za Rzymem i coraz boleśniej odczuwa rozstanie się z wielkim miastem, jego teatrami i bibliotekami, a wreszcie ludźmi, dzięki obcowaniu z którymi „studere se voluptates non sentiunt". 
współobywateli, że w takim przypadku zechce wrócić do stolicy imperium ${ }^{29}$.

Do Rzymu jednak Marcjalis, jak wiemy, już nie powrócił. Oficjalnie przyjmuje się, że dość wczesna śmierć udaremniła jego powrót do upragnionego ponownie życia wielkomiejskiego ${ }^{30}$. Czy jednak, nawet idealizując z perspektywy dalekiej prowincji ów świat wielkiego Rzymu, nosił on się z takim zamiarem? Tego rodzaju supozycja znajduje dość słabe potwierdzenie zarówno w faktach, jak też w deklaracjach poety, które znajdujemy w dwunastej księdze jego epigramów, powstałej już w czasie jego rozłąki ze stolicą imperium. Znajdziemy tam, owszem, pewne dość konwencjonalne pochwały Rzymu, a zwłaszcza jego ówczesnych imperatorów, lecz samego obrazu życia w tym mieście Marcjalis z całą pewnością nie idealizuje. Na obraz ten składają się zarówno budzące jego sprzeciw obyczajowe wynaturzenia (XII,47), jak też zgiełk i uciążliwości sprawiające, że już wtedy najchętniej ucieka w zacisze swej wiejskiej posiadłości (XII,57), jak wreszcie zmęczenie i permanentny brak snu wspominane w epigramie, który kieruje poeta do jakiegoś nękającego go i w rodzinnej miejscowości „klienta” 31 . W tym też epigramie zdradza poniekąd, jaki jest jego stan wewnętrzny w owych ostatnich już latach życia. Określa siebie jako człowieka w zaawansowanym wieku, nie tylko wyzbytego polemicznej werwy, lecz w ogóle pozbawionego jakiejś większej aktywności życiowej ${ }^{32}$.

29 Por. Howell, 1998: 181: „However, there is evidence in the book that things did not work out so well. Already at 10.103, when hinting at his intention to return to Bilbilis, he had warned its municipies (11-12): Excipitis placida reducem si mente, venimus; Aspera si geritis corda, redire licet".

30 Por. Martial, 2003: 4: „Death prevented his returning to Rome, but this was not a realistic prospect in any case".

31 XII,68,5-6: „Otia me somnusque iuvant, quae magna negavit / Roma mihi: redeo, si vigilatur et hic”; por. XII,57,27-28: „Et ad cubilest Roma. Taedio fessis / Dormire quotiens libuit, imus ad villam".

32 XII,68,3-4: „Non sum ego causidicus, nec amaris litibus aptus, / Sed piger et senior Pieridumque comes". 
Respektując tę deklarację, można uznać, że powrócił nasz poeta do miejsc rodzinnych jako człowiek już spełniony w życiu i twórczości, którą z powodzeniem przez lata uprawiał, zarazem jako człowiek intelektualnie i emocjonalnie na tyle „wyeksploatowany", że zamierzał jedynie w owych bliskich mu miejscach spokojnie dokonać swojego żywota, nie biorąc raczej pod uwagę trudów, jakie wiązałyby się z powrotem do Rzymu i ponowną $\mathrm{w}$ nim adaptacją.

Ów zamiar realizował się oczywiście w sposób niejednoznaczny, czego wyrazem jest zmienność akcentów, z jakimi poeta odnosi się zarówno do swej sytuacji aktualnej, przedstawianej bądź enkomiastycznie i wręcz sielankowo, bądź w sposób mocno krytyczny, jak też do swej wielkomiejskiej przeszłości, budzącej tak niejednoznaczne reminiscencje. Dając wielokrotnie wyraz tej rozterce, która zresztą odzywa się także we wcześniejszych jego utworach, Marcjalis pozostanie człowiekiem, który nieodmiennie tkwi „na krawędzi między dwiema swoimi ojczyznami”33.

\section{Bibliografia}

Antczak, K. (2016): Obraz Hiszpanii w Historii Naturalnej Pliniusza Starszego. Poznań: Wydawnictwo PTPN.

Baumbach, M. (2004): Gelobtes Land, w: G. Damschen und A. Heil (red.), Marcus Valerius Martialis: Epigrammaton liber decimus. Das zehnte Epigrammbuch. Text, Übersetzung, Interpretationen. Mit einer Einleitung, Martial-Bibliographie und einem rezeptionsgeschichtlichen Anhang. Frankfurt am Main: 341-342.

Cytowska, M., Szelest, H. (1992): Literatura rzymska. Okres cesarstwa. Warszawa: PWN.

33 Por. Niehl, 2004: 368: „So vollzieht sich ein Blickwechsel von Rom in die spanische Heimat und von Martials jüngerer Vergangenheit und Gegenwart zu seiner weiteren Vergangenheit und Zukunft. Diese doppelte Widmung passt zum zehnten Buch, in dem der Dichter an der Schwelle zwischen seinen beiden Heimaten steht". 
Dalby, A. (2000): Empire of Pleasures. Luxury and Indulgence in the Roman World. London-New York: Psychology Press.

Damschen, M.V. (2004): Bilbils' Ehrenbürger - w: G. Damschen und A. Heil (red.), Marcus Valerius Martialis: Epigrammaton liber decimus: Text,Übersetzung, Interpretationen. Frankfurt am Main: P. Lang: 362.

Howell, P. (1998): Toto notus in orbe. Perspektiven der Martial-Interpretation. Stuttgart: Steiner.

Heraeus, W. (red.) (1925): M. Valerii Martialis Epigrammaton libri XIV. Bibliotheca scriptorum Graecorum et Romanorum Teubneriana. Lipsk.

Merli, E. (2006): Martial between Rome and Bilbilis, w: R.M. Rosen City (red.), Countryside, and the Spatial Organization of Value in Classical Antiquity. Leiden: Brill: 327-347.

Niehl, R. (2004): Dem Buch zu Geleit, w: G. Damschen und A. Heil (red.), Marcus Valerius Martialis: Epigrammaton liber decimus. Das zehnte Epigrammbuch. Text, Übersetzung, Interpretationen. Mit einer Einleitung, Martial-Bibliographie und einem rezeptionsgeschichtlichen Anhang. Frankfurt am Main: 367-368.

Soldevila R.M. (red.) (2006): Martial, Book IV. A Commentary. Leiden-Boston: Brill.

Sullivan, J.P. (2004): Martial: The Unexpected Classic. A Litterary and Historical Study. New York: Cambridge University Press.

Szelest, H. (1963): Marcjalis i jego twórczość. Wrocław. Ossolineum.

Watson, L. and Watson, P. (red.) (2003): Martial: Select Epigrams. Cambridge: Cambridge University Press. 